\title{
PEMODELAN PASANG SURUT DENGAN MENGGUNAKAN METODE FLEXIBLE MESH UNTUK MENGETAHUI GENANGAN ROB DI PESISIR KARAWANG
}

\author{
TIDE MODELING USING FLEXIBLE MESH METHOD TO DETERMINE \\ ROB FLOODS IN THE COASTAL KARAWANG
}

\section{Herlina Adelina M. U. Sagala, Roberto Patar Pasaribu*, Fafthia Karimatul Ulya}

Politeknik Kelautan dan Perikanan Karawang, Jalan Lingkar Tanjungpura, Karangpawitan, Kecamatan Karawang Barat, Kabupaten Karawang, Jawa Barat, Indonesia

Teregistrasi I tanggal: 11 Agustus 2021; Diterima setelah perbaikan tanggal: 29 September 2021; Disetujui terbit tanggal: 30 September 2021

\begin{abstract}
ABSTRAK
Pasang surut air laut merupakan salah satu gejala alam yang tampak di laut, yakni gerakan naik turunnya muka air laut. Gerakan tersebut disebabkan oleh pengaruh gaya tarik menarik antara bumi, bulan dan matahari. Data pasang surut dapat memberikan gambaran hidrodinamika di daerah pesisir dan dapat digunakan untuk perencanaan pembangunan dan mitigasi bencana di wilayah pesisir. Untuk mengetahui pasang surut dapat dilakukan dengan pengukuran langsung di lapangan atau dapat dilakukan dengan pemodelan. Penelitian ini bertujuan untuk membuat pemodelan pasang surut pantai Karawang dan dimanfaatkan untuk mengetahui genangan rob yang sering terjadi di pesisir Karawang. Metode yang digunakan dalam pemodelan pasang surut ini adalah Metode Flexible Mesh Simulasi yang terdapat pada Software Mike 2 dengan mengunakan data batimetri, garis pantai dan topografi. Hasil pemodelan pasang surut di perairan Karawang diketahui tipe pasang surut adalah tipe campuran condong harian tunggal dengan nilai Fomzhal adalah 2.854. Pasang tertinggi terjadi pada 8 Maret 2021 dengan interval waktu selama 2 jam dan elevasi berkisar 0.20-0.42m. Prediksi genangan banjir rob tertingi terjadi pada pada 13 Maret 2021 dengan interval waktu selama 3 jam dan nilai elevasi berkisar 0.11-0.15 m berada pada pesisir Kecamatan Pedes dengan dengan luasan genangan $38,69 \mathrm{~km} 2$.
\end{abstract}

Kata kunci: Pasang Surut; Genangan Rob; Pemodelan; Software Mike 21

\section{ABSTRACT}

The tides are one of the natural phenomena that appear in the sea, namely the movement of rising and falling sea levels. The movement is caused by the influence of the attractive forces between the earth, moon and sun. Tidal data can provide an overview of hydrodynamics in coastal areas and can be used for development planning and disaster mitigation in coastal areas. To find out the tides can be done by direct measurements in the field or can be done by modeling. This study aims to model the tides of the Karawang coast and is used to determine the tidal inundation that often occurs on the coast of Karawang. The method used in this tidal modeling is the Flexible Mesh Simulation Method found in Mike 2 Software using bathymetry, coastline and topography data. From the results of tidal modeling in the Karawang Waters, it is known that the tidal type is a mixed type with a single daily slope and the Fomzhal value is 2.85. The highest tide will occur on March 8,2021 with an interval of 2 hours and an elevation of 0.20-0.42m. Prediction of the highest tidal flood inundation will occur on March 13, 2021 with an interval of 3 hours and an elevation value ranging from 0.11-0.15 m on the coast of Pedes District with an inundation area of $38.69 \mathrm{~km} 2$.

Keywords: Tides; Tidal Inundation; Modeling; Mike 21 Software

\footnotetext{
Korespondensi penulis:

*Email: roberto_pasa@yahoo.com
}

DOI: http://dx.doi.org/10.15578/plgc.v2i3.10341 


\section{PENDAHULUAN}

Pasang surut merupakam proses naik turunnya permukaan air laut karena gaya tarik benda-benda luar angkasa seperti bulan dan matahari (Saputra, 2007). Sehingga dapat diartikan bahwa pasang surut memiliki sifat terjadi secara periodik atau berkelanjutan. Hal ini yang menyebabkan tinggi permukaan air laut memiliki nilai yang tetap akan tetapi bergerak naik turun dengan periode waktu yang berbeda (Richasari et al., 2019).

Pasang surut purnama terjadi pada saat bumi, bulan dan matahari berada dalam satu garis lurus. Pada saat itu, terjadi pasang tertinggi dan pasang terendah, karena kombinasi gaya tarik matahari dan bulan bekerja saling menguatkan. Pasang-surut purnama terjadi dua kali setiap bulan yaitu pada saat bulan purnama sedangkan pasangsurut perbani terjadi pada saat bumi, bulan dan matahari tegak lurus membentuk sudut $90^{\circ}$ dengan bumi. Pada saat itu dihasilkan pasang tinggi yang rendah dan pasang rendah yang tinggi. Pasang-surut perbani ini terjadi dua kali, yaitu pada saat bulan 1/4 dan 3/4 (Musrifin, 2011).

Banjir rob adalah gejala alam, yang terjadi pada saat kondisi bulan penuh atau bulan purnama. Pada saat itu gaya gravitasi bulan terhadap bumi sangat kuat sehingga gerak air laut ke arah pantai lebih kuat ketimbang pada hari-hari biasa. Jadi rob, adalah istilah untuk menyebut luberan air laut ke darat ketika air laut pasang (Dewi, 2010). Banjir rob mengenangi bagian daratan pantai atau tempat yang lebih rendah dari muka air laut pasang tinggi (high level water) (Karana \& Supriharjo, 2013).

Kawasan pesisir adalah kawasan yang amat rentan dengan tekanan lingkungan, baik yang berasal dari laut maupun dari daratan (Utami et al., 2017). Salah satu tekanan yang mengancam keberlangsungan dari Kawasan pesisir adalah adanya permukaan air laut (Wirasatriya et al., 2006). Pesisir utara Karawang merupakan salah satu contoh dari Kawasan pesisir yang rentan tersebut.

Kawasan pesisir utara Karawang merupakan wilayah yang rentan terhadap terjadinya banjir pasang (rob) akibat pengaruh pasang surut air laut. Kondisi ini terjadi pada saat pasang tertinggi dan menggenangi wilayah yang elevasinya lebih rendah. Limpasan air laut akan mengalir ke tempat yang lebih rendah sehingga menggenangi daerah tersebut (Marfai et al., 2013). Bencana banjir rob dan penurunan muka tanah berpotensi memperluas daerah genangan banjir rob (Marfai et al., 2008).

Segala aktifitas yang berada di Pesisir Karawang membutuhkan pemahaman hidrodinamika pantai yang digunakan untuk meminimalisir terjadinya kerusakkan di Pesisir Karawang. Berdasarkan pengamatan data hidro-oseanografi yang terdiri dari arus laut, gelombang laut, dan pasang surut pantai Karawang telah mengalami kerusakan pantai. (Agus et al., 2020). Dalam menyikapi suatu permasalahan tersebut ada berbagai macam cara, diantaranya dengan membuat pemodelan hidrodinamika dimana lebih hemat dalam biaya, tidak membutuhkan banyak tempat untuk memodelkan. Salah satu pemodelan hidrodinamika adalah pemodelan pasang surut air laut. Pemodelan pasang surut yang sering digunakan adalah pemodelan dengan menggunakan metode flexible mesh yang terdapat pada Software MIKE 21 yaitu aplikasi yang digunakan untuk mempermudah dalam pemodelan oseanografi.

Software MIKE 21 merupakan software yang digunakan dalam berbagai pemodelan seperti pemodelan arus, gelombang, pasang surut dan sebagainya. Software Mike 21 dipakai dalam memprediksi parameter yang akan diukur dengan membuat model hidrodinamika. 
Model hidrodinamik dalam Mike $21 \mathrm{HD}$ adalah sistem model numerik umum untuk muka air dan aliran di estuari, teluk dan pantai (Irwan et al., 2020). Software MIKE 21 sendiri dibuat oleh Danish Hydrodinamic Institute (DHI) pada Tahun 1992, yaitu program komputer yang digunakan untuk mensimulasikan proses fisik, kimia dan biologi yang mencakup aliran permukaan dalam bentuk 2D (DHI, 2017). Verifikasi arus model Mike 21 dengan arus pasang surut diperoleh nilai MRE (Mean Relative Error) rata-rata sebesar 33,75\% sehingga simulasi model hidrodinamika 2D menggunakan Mike 21 dapat dikatakan mampu mempresentasikan kondisi hidrodinamika di daerah pengamatan (Leksono et al., 2013).

Metode Flexible mesh Model Flow Model adalah komprehesif system pemodelan untuk dua ataupun tiga dimensi pada pemodelan pesisir yang dikembangkan oleh DHI Water dan Living Environment. Pemodelan 2D dilakukan berdasarkan pendekatan Flexible Mesh dimana struktur atau objek dibuat menjadi bagian-bagian kecil berbentuk segitiga maupun quadrilateral (bentuk geometri dengan empat sisi) yang tidak terstruktur yang memiliki batasan berupa garis yang terbentuk dari titik-titik (nodes) tiap elemen (DHI, 2017).

Penelitian ini bertujuan untuk membuat pemodelan pasang surut pantai Karawang dengan mengunakan Metode Flexible Mesh yang ada pada Software MIKE 21. Dengan adanya pemodelan pasang surut ini sangat membantu memahami tentang pasang surut. Pemodelan ini juga digunakan untuk memprediksi genangan banjir rob yang sering terjadi di pesisir Karawang. Disamping itu penelitian ini dapat memberikan informasi dan gambaran hidrodinamika pantai yang dapat dipakai dalam perencanaan pembangunan dan mitigasi bencana, pengembangan pariwisata maupun pengelolaan kelautan dan perikanan di wilayah pesisir kabupaten Karawang.

\section{BAHAN DAN METODE}

Lokasi dan Waktu Penelitian

Lokasi penelitian berada di pesisir Karawang yang meliputi sembilan kecamatan yaitu Cilamaya Kulon, Cilamaya Wetan, Tempuran, Pedes, Cilebar, Cibuaya, Tirtajaya, Batujaya, dan Pakis Jaya. Lokasi pengamatan dapat dilihat pada Gambar 1. Kegiatan dilaksanakan pada bulan Maret-Juni 2021.

\section{Alat dan Bahan}

Peralatan dan bahan yang digunakan dalam mengumpulkan dan mengolah data dapat dilihat pada Tabel 1 .

\section{Jenis dan Sumber Data}

Data yang digunakan dalam aplikasi Mike 21 berasal dari beberapa sumber yaitu:

a. Peta Batimetri tahun 2021, dari Peta Lingkungan Pantai Indonesia (BIG https://portal.ina-

sdi.or.id/downloadaoi/) yang didownload 1 Maret 2021.

b. Peta Garis Pantai tahun 2021, dari Peta Lingkungan Pantai Indonesia (BIG https://portal.inasdi.or.id/downloadaoi/) yang didownload 1 Maret 2021.

c. Data Pasang Surut tahun 2021, dari data prediksi pasut global yang tersedia di MIKE 21.

d. Peta Topografi Peta Lingkungan Pantai Indonesia (BIG https://portal.inasdi.or.id/downloadaoi/) yang didownload 1 Maret 2021. 


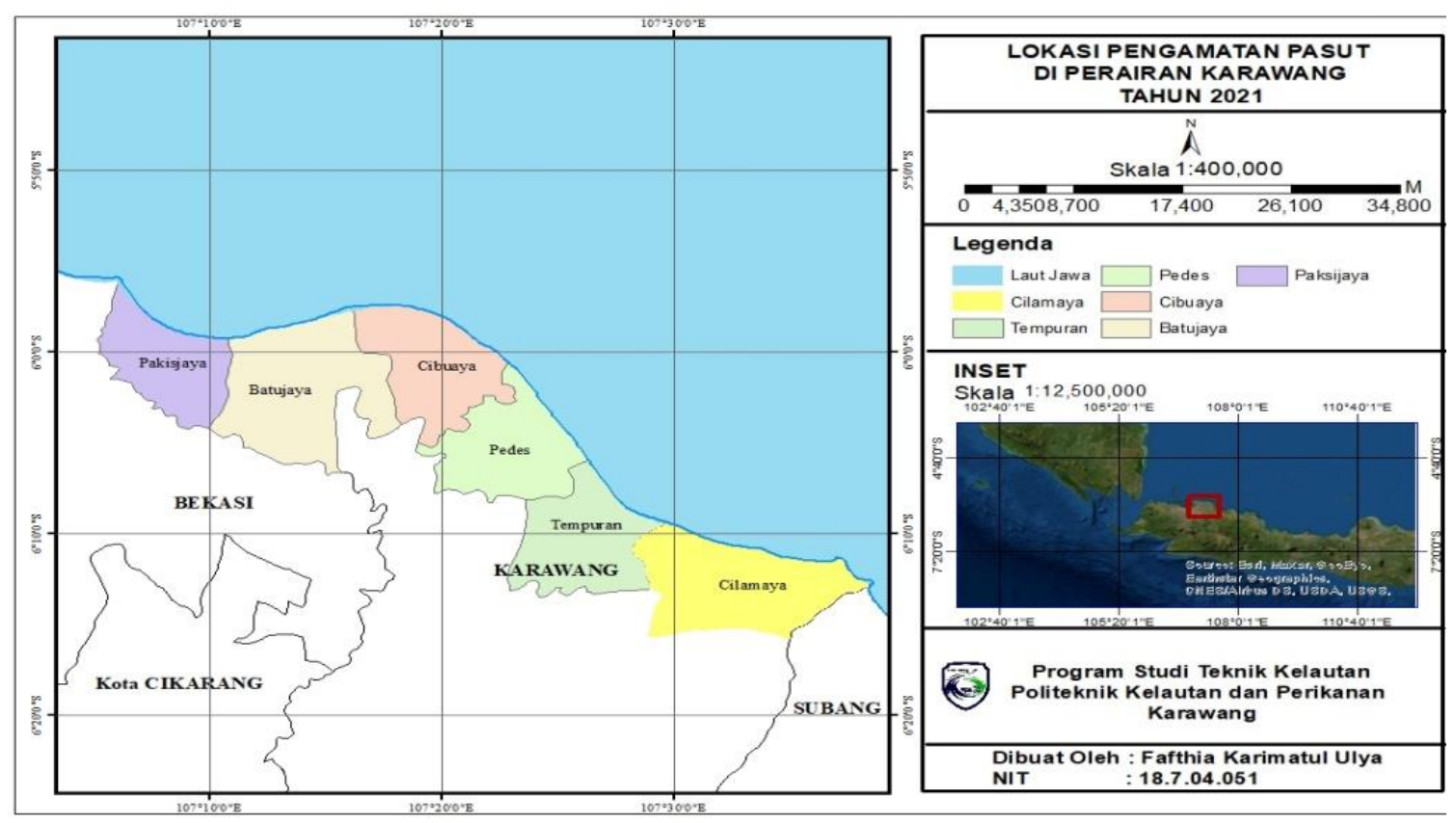

Gambar 1. Lokasi Pengamatan di Pesisir Karawang

Figure 1. Location of the Karawang Coastal Observation

\section{Metode Pemodelan}

Metode dalam pemodelan ini menggunakan metode Flexible mesh yang terdapat pada Software MIKE 21 flowmodel. Tujuan pemodelan ini untuk menghasilkan model pasang surut pesisir Karawang. Adapun langkah-langkah untuk memodelkan pasang surut adalah:

a) Pengumpulan Data

Data yang dikumpulkan adalah data pasang surut, batimetri dan topografi yang diperoleh dari Badan Informasi Geospasial (BIG) dengan area sekitar pantai Karawang.

b) Pemasukan Data

Data yang dimasukkan adalah pasang surut dan batimetri sebagi input data dalam pemodelan.

c) Pembuatan Grid

Pembuatan grid pada meshing diperlukan untuk memunculkan koordinat pada layar meshing yang kemudian input data garis pantai dan data batimetri.

d) Set Up Model

Set up model hasil meshing berupa file ke domain model dan input data pasang surut hasil olahan software Mike 21.

e) Running Model

Running Model pada Mike 21 untuk mendapatkan hasil model pasang surut dan genangan rob pesisir Karawang

f) Hasil Model

Hasil model dari pemodelan pasang surut dan genangan rob pesisir Karawang berupa gambar / peta.

Untuk membuat pemodelan pasang surut dengan Mike 21 dilakukan dengan melakukan persiapan awal dan melakukan simulasi. Persiapan awal adalah menyiapkan data garis pantai dan kedalaman pesisir di daerah pengamatan, hasil dari proses tersebut menghasilkan format data untuk garis pantai dan posisi kedalaman pesisir. Kegiatan simulasi dilakukan dalam beberapa tahapan yaitu, 1) membuat area kerja; 2) pemanggilan data; 3 ) membuat batasan model; 4) input batimetri; 5) interpolasi data batimetri; dan 6) running model. 
Tabel 1. Alat dan Bahan

Table 1. Tools and Materials

\begin{tabular}{lll}
\hline No & Nama Alat & Fungsi \\
\hline 1 & Alat tulis & Untuk mencatat data skunder \\
2 & Laptop & Sebagai alat untuk mengolah data \\
3 & Software Mike 21 & Untuk running model data pasang surut \\
4 & Kamera & Untuk mengambil gambar \\
5 & Microsoft Word & Untuk menyusun laporan \\
\hline
\end{tabular}

Area kerja dibuat untuk membatasi lokasi pengamatan sehingga dapat di input data untuk memodelkan pasang surut. Area kerja digunakan untuk melakukan editing terkait model yang akan di input. Area kerja ini dibatasi latitude dan longitude lokasi pantai kemudian dilakukan input data, yaitu data garis pantai dan data batimetri. Data garis pantai dan batimetri ditentukan pada daerah pengamatan yang akan dimodelkan. Langkah selanjutnya yaitu running model dengan menentukan pengukuran waktu running yaitu satu bulan (30 hari) pada bulan Maret 2021 dengan interval waktu 1 jam.

Pemodelan Mike 21 dalam tahap awal pemodelan dilakukan editing mesh. Element mesh dibentuk dari garis pantai dan kedalaman pesisir di daerah pengamatan. Project baru dalam pemodelan diperlukan persiapan terlebih dahulu terkait informasi lokasi atau domain area yang diperlukan dalam pemodelan. Informasi tersebut meliputi data kedalaman pesisir (batimetri) dan data garis pantai. Dalam pembuatan file project baru diperlukan beberapa tahapan mulai membuat area kerja sampai output model.

\section{HASIL DAN BAHASAN \\ HASIL}

Pemodelan Mike 21

Untuk melakukan pemodelan Mike 21 diperlukan data-data yaitu data batimeri, data garis pantai, data pasang surut dan data topografi (Hiwari \& Subiyanto, 2020). Data tersebut di peroleh dari Peta LPI (Lingkungan Pantai Indonesia) dengan cara mendownload pada titik kordinat yang akan digunakan.

Data Batimetri dan Garis Pantai berupa format XYZ, yaitu $\mathrm{XY}$ menunjukan posisi dan $\mathrm{Z}$ menunjukkan kedalaman, data garis pantai dalam format XY menunjukkan posisi. Data ini kemudian disesuaikan dengan format data yang ada di MIKE 21. Kedua data tersebut di extrak menggunakan bantuan Software SAGA GIS untuk menghasilkan data menjadi XYZ sehingga dapat di input kedalam MIKE 21.

Data pasang surut yang berupa lokasi, waktu dan tinggi muka air diperoleh dari data prediksi global yang tersedia di MIKE 21 dengan periode waktu selama satu tahun (Januari 2021Desember 2021) dengan interval waktu satu jam.

Data Topografi merupakan data ketinggian permukaan tanah pada suatu daerah terhadap permukaan laut dan digambarkan dengan garis-garis kontur pada peta topografi. Data-data tersebut setelah didownload kemudian disesuaikan dengan format data Mike 21. Data batimetri dan garis pantai yang digunakan dalam pemodelan Mike 21 terdapat pada Gambar 2.

\section{Tahapan Pemodelan}

\section{1). Membuat Area Kerja \\ Dalam melakukan pengerjaan} pemodelan Mike 21 diperlukan area kerja yang didalamnya untuk membuat mesh sehingga dapat di input untuk memodelkan pasang surut. Pada tahapan 
ini area kerja digunakan untuk melakukan editing terkait model yang akan di input. Tahapannya adalah buka software Mike 21 dengan membuat Workspace projection dan pilih Projection yang sesuai dengan data, dalam pemodelan ini

\begin{tabular}{|c|c|c|}
\hline \\
\hline \multicolumn{3}{|c|}{$\begin{array}{l}\text { - bati_Karawang-Notepad } \\
\text { Fle Edit Format View Help }\end{array}$} \\
\hline 108.574734 & -6.173467 & .38 \\
\hline 108.574178 & -6.173106 & .38 \\
\hline 188.57394 & -6.172985 & -38 \\
\hline 108.573742 & -6.172785 & -38 \\
\hline 108.573425 & -6.172285 & .30 \\
\hline 108.573386 & -6.172885 & -38 \\
\hline 108.573228 & -6.171866 & .38 \\
\hline 108.573149 & -6.171646 & .38 \\
\hline 108.57311 & -6.171427 & .38 \\
\hline 108.573112 & -6.178988 & .30 \\
\hline 108.573154 & -6.17055 & -30 \\
\hline 108.573276 & -6.178132 & .38 \\
\hline 108.573437 & -6.169714 & -30 \\
\hline 108.573638 & -6.169297 & .30 \\
\hline 108.574899 & -6.168581 & -30 \\
\hline 108.574881 & -6.167529 & -30 \\
\hline 108.575818 & -6.167274 & -30 \\
\hline 108.576675 & -6.167099 & -30 \\
\hline 108.577094 & -6.167841 & -30 \\
\hline 108.577552 & -6.167023 & -30 \\
\hline 108.578049 & -6.167065 & -30 \\
\hline 108.578687 & -6.167148 & -30 \\
\hline 108.57936 & -6.167889 & -30 \\
\hline
\end{tabular}

projection yang digunakan adalah LONG/LAT. Gambar 3 merupakan tahap pemilihan menu mesh generator untuk pembuatan mesh dalam Mike 21 untuk meng-input data garis pantai dan batimetri dalam format xyz.

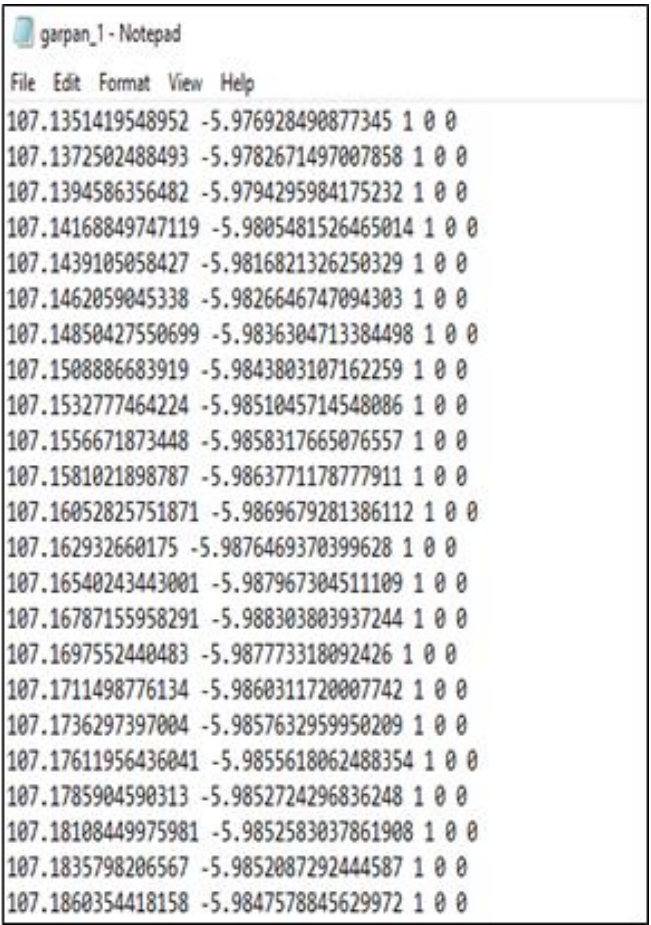

Gambar 2. Input Data Model

Figure 2. Model Data Input

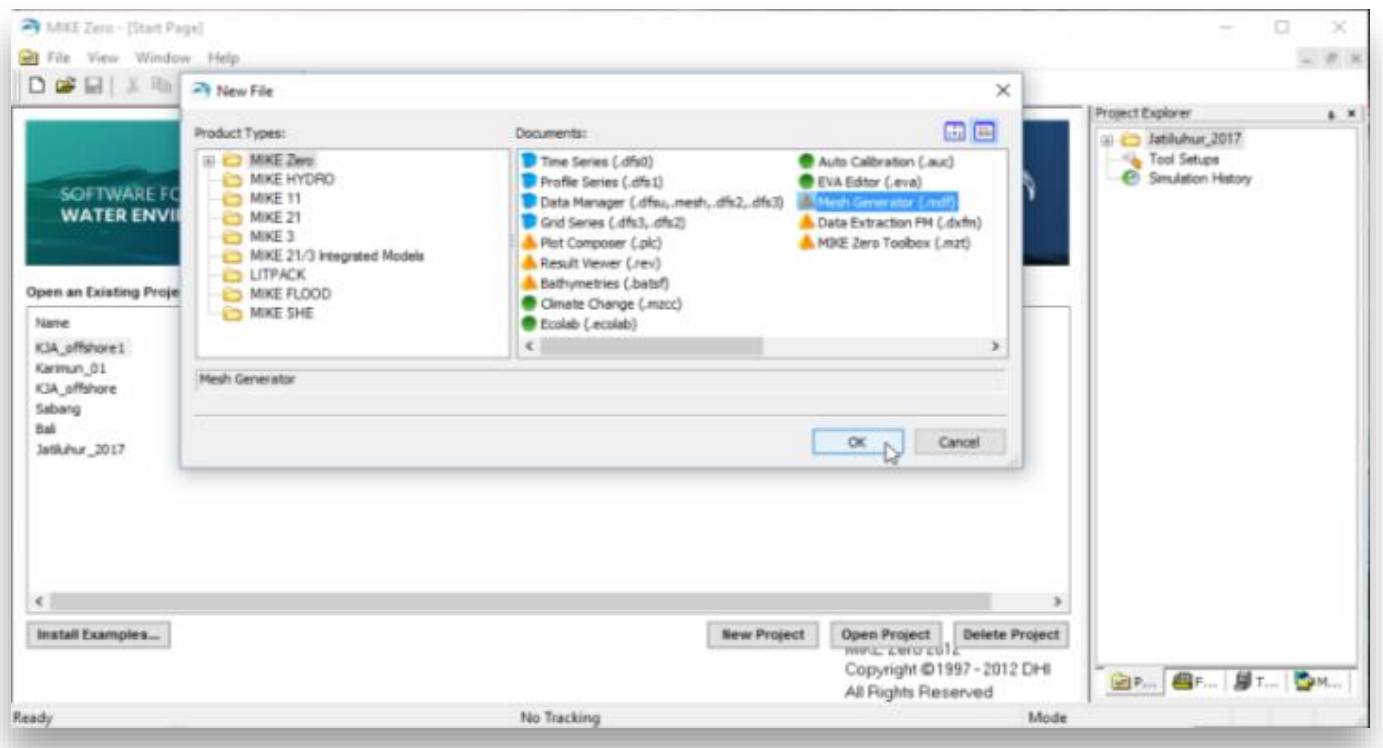

Gambar 3. Laman Pilihan Mesh Generator

Figure 3. Mesh Generator Options Page 


\section{2). Pemanggilan Data}

Tahapan selanjutnya setelah area kerja dilakukan pemanggilan data/input data garis pantai dan data kedalaman pesisir kedalam layar area kerja. Tahapannya adalah import boundary, pilih file garis pantai yang akan digunakan. Dalam pemodelan ini file yang digunakan adalah pesisir karawang. Selanjutnya tentukan column sequence yang sesuai (X,Y and Connectivity), selanjutnya akan muncul dilayar kerja MIKE 21 garis pantai daerah model.

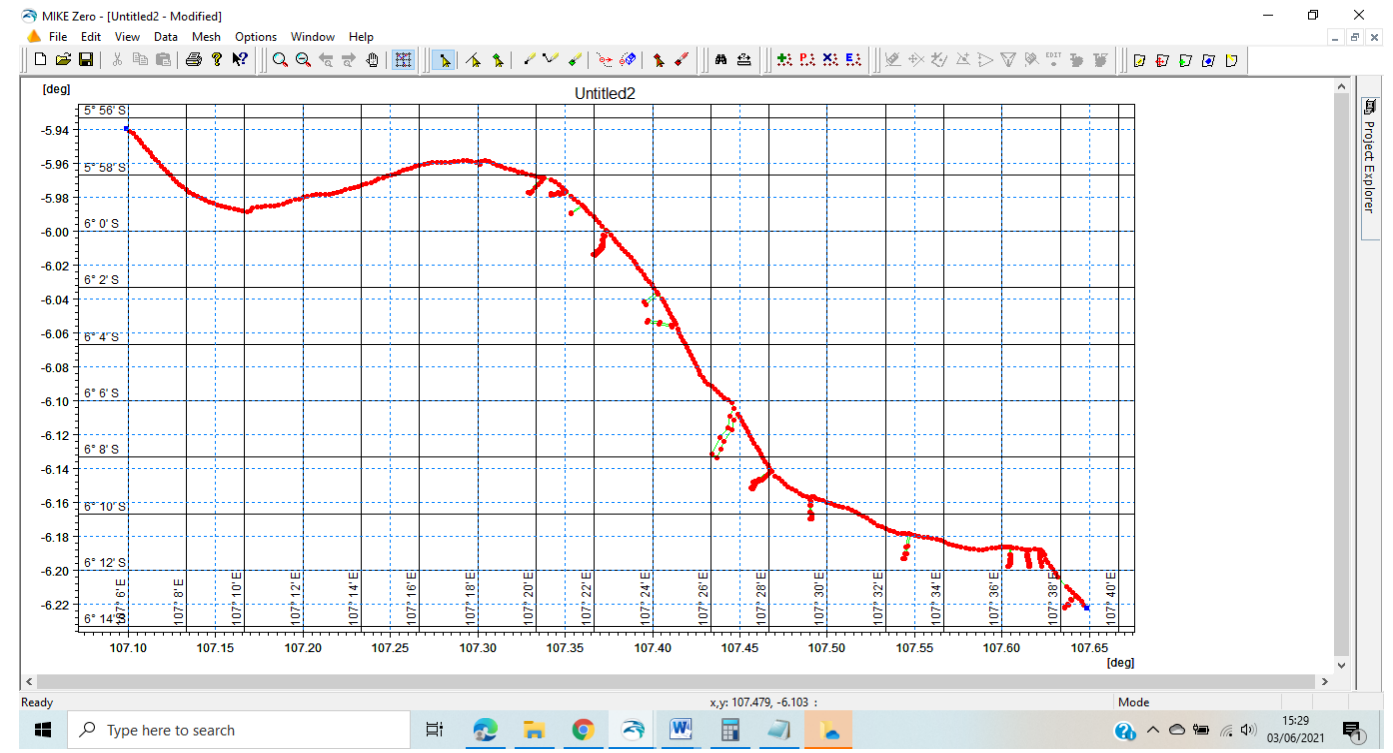

Gambar 1. Tampilan Workspace Garis Pantai

Figure 4. Coastline Workspace View

3). Membuat Batasan Model

Batasan Model dilakukan dengan membuat batas maksimum dan minimm dari lokasi. Mesh pada Gambar 5 menunjukkan hasil pengolahan meshing dengan ketelitian mesh maximum 0.0001 deg, derajat 26 dan minimum node tidak lebih dari 100000.

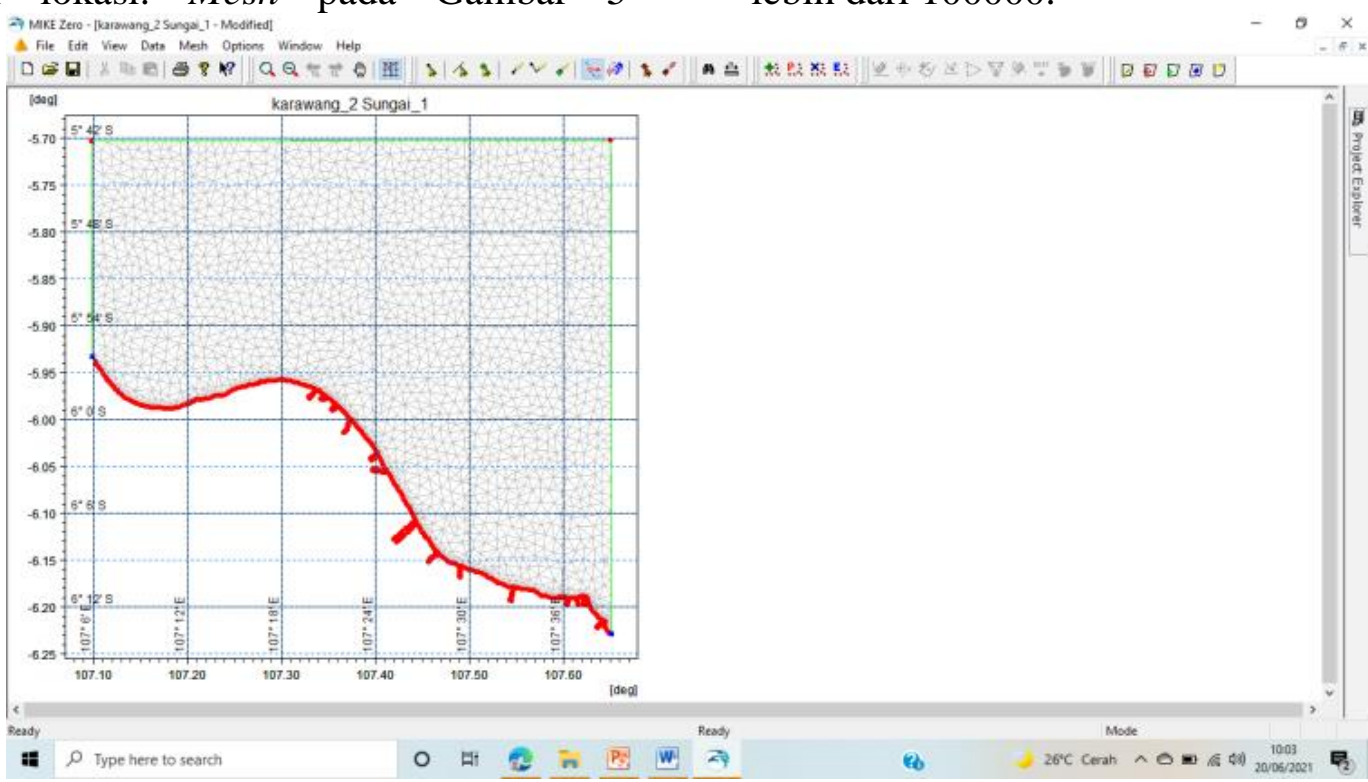

Gambar 5. Mesh Model

Figure 5. Mesh Model 
4). Input Batimetri

Setelah data garis pantai tersedia di area kerja maka langkah selanjutnya yaitu memasukkan data batimetri sebagai input data. Data batimetri ditentukan pada daerah pengamatan yang akan dimodelkan. Dalam pemodelan ini file yang digunakan adalah pesisir Karawang. Selanjutnya akan muncul pop up Manage Scater Data, kemudian tentukan file yang akan di input dan convert from LONG/LAT lalu muncul batimetri pada lembar kerja mesh.

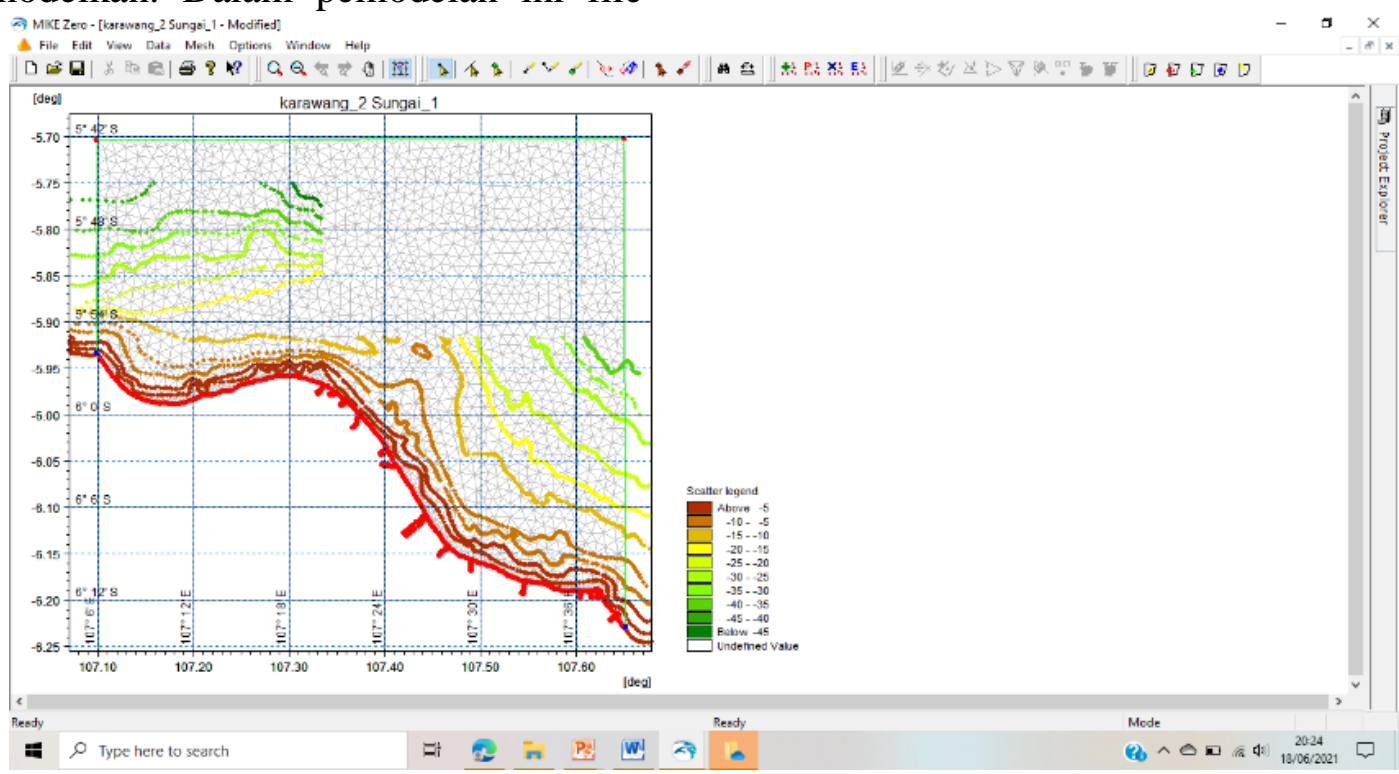

Gambar 6. Hasil input Batimetri

Figure 6. Bathymetry input results

\section{5). Interpolasi Data Batimetri}

Setelah input data batas model dan batimetri maka langkah selanjutnya adalah interpolasi data batimetri menjadi data grid. Pada langkah ini dilakukan import data batimetri untuk selanjutnya diinterpolasi menjadi data input model.

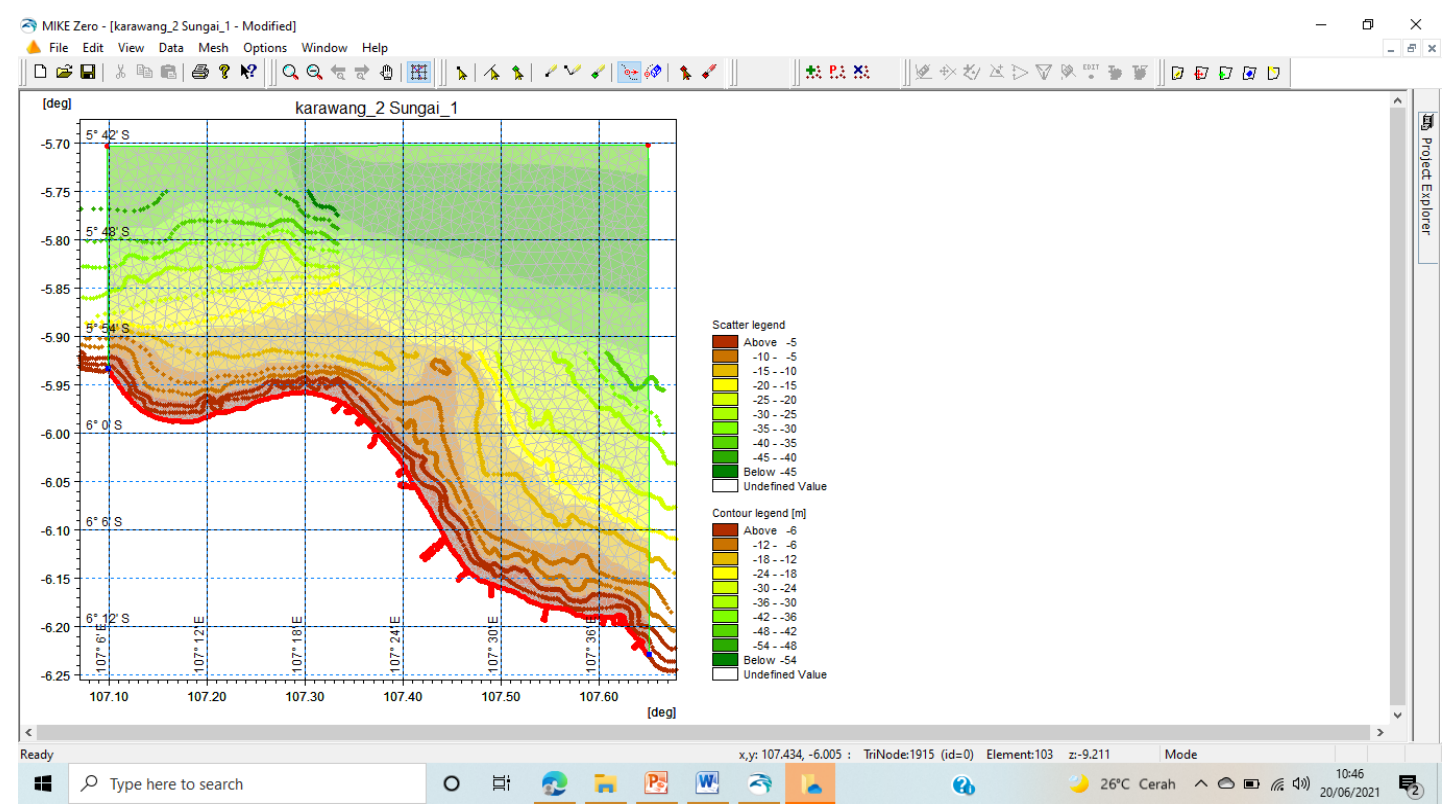

Gambar 7. Hasil interpolasi

Figure 7. Interpolation results 


\section{6). Running Model}

Setelah data mesh garis pantai dan batimetri tersedia di area kerja maka langkah selanjutnya yaitu running model dengan membuat laman baru pada file dengan memasukkan hasil mesh data batimetri dan garis pantai. Kemudian menetukan pengukuran waktu running pada lembar kerja mesh. Dengan mengatur domain model pada laman mesh file, kemudian mengatur boundary condition dengan memasukkan data pengolahan pasang surut selama 1 tahun yang di olah sebelumnya kedalam boundary condition, setelah itu running model.

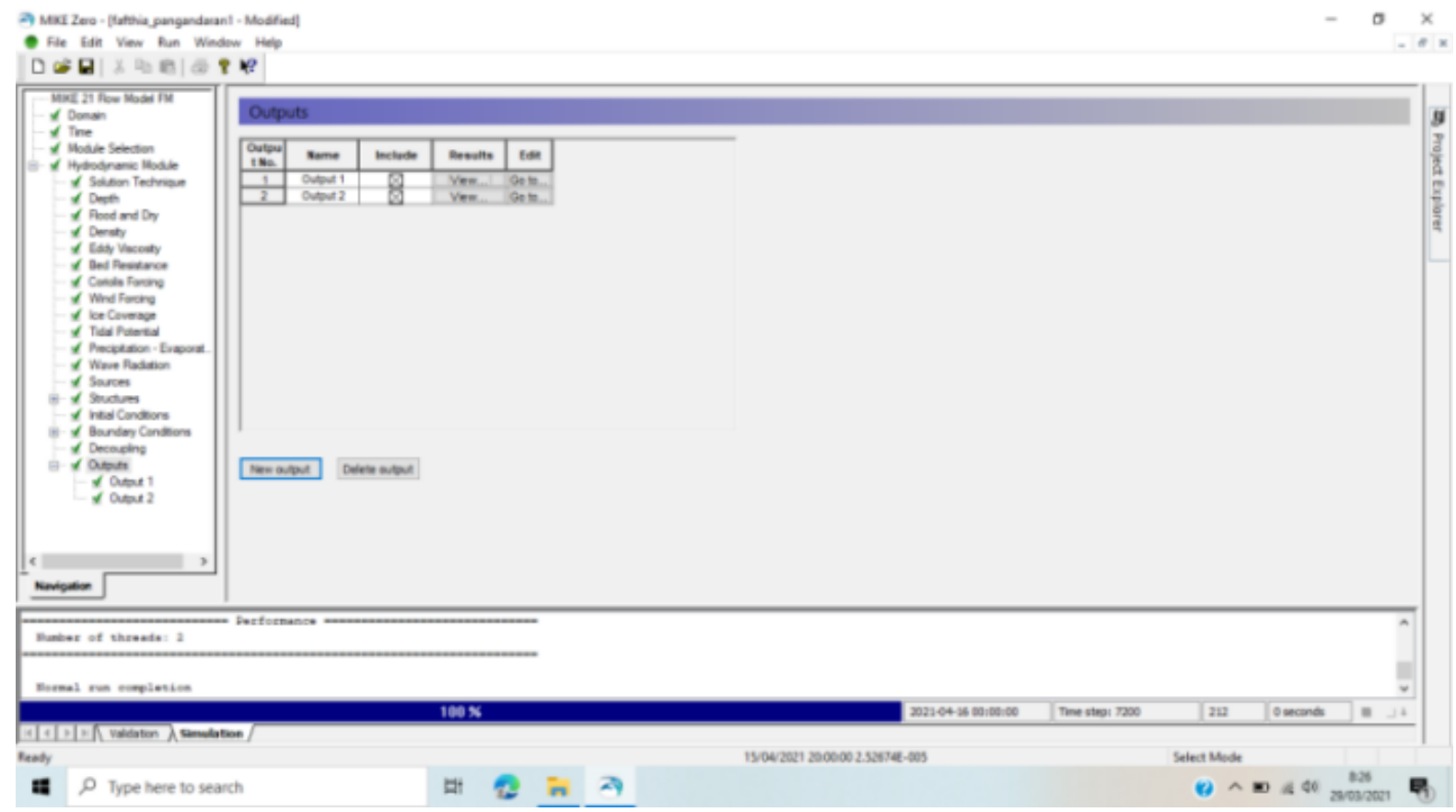

Gambar 8. Running Completion

Figure 8. Running Completion

\section{Perhitungan Komponen Pasang Surut}

Hasil simulasi pemodelan pasang surut menggunakan Mike 21 dengan modul Flow Model FM dengan interval waktu 1 jam selama 30 hari yang di dapatkan dari global tide Mike 21 dapat menghasilkan nilai komponen pasang surut, yaitu komponen harian tunggal (K1 dan O1) dan komponen harian ganda (M2 dan S2). a. Komponen harian tunggal (K1 dan O1)

Hasil pemodelan pasang surut di pesisir Karawang memperoleh hasil untuk komponen pasang surut utama $\mathrm{O} 1$ Amplitudo dengan nilai antara 0.072 0.128 (Gambar 9). Peta pasang surut di pesisir Karawang dengan hasil komponen utama pasang surut K1 Amplitudo nilai sebesar $0.12-0.25$ (Gambar 10). 


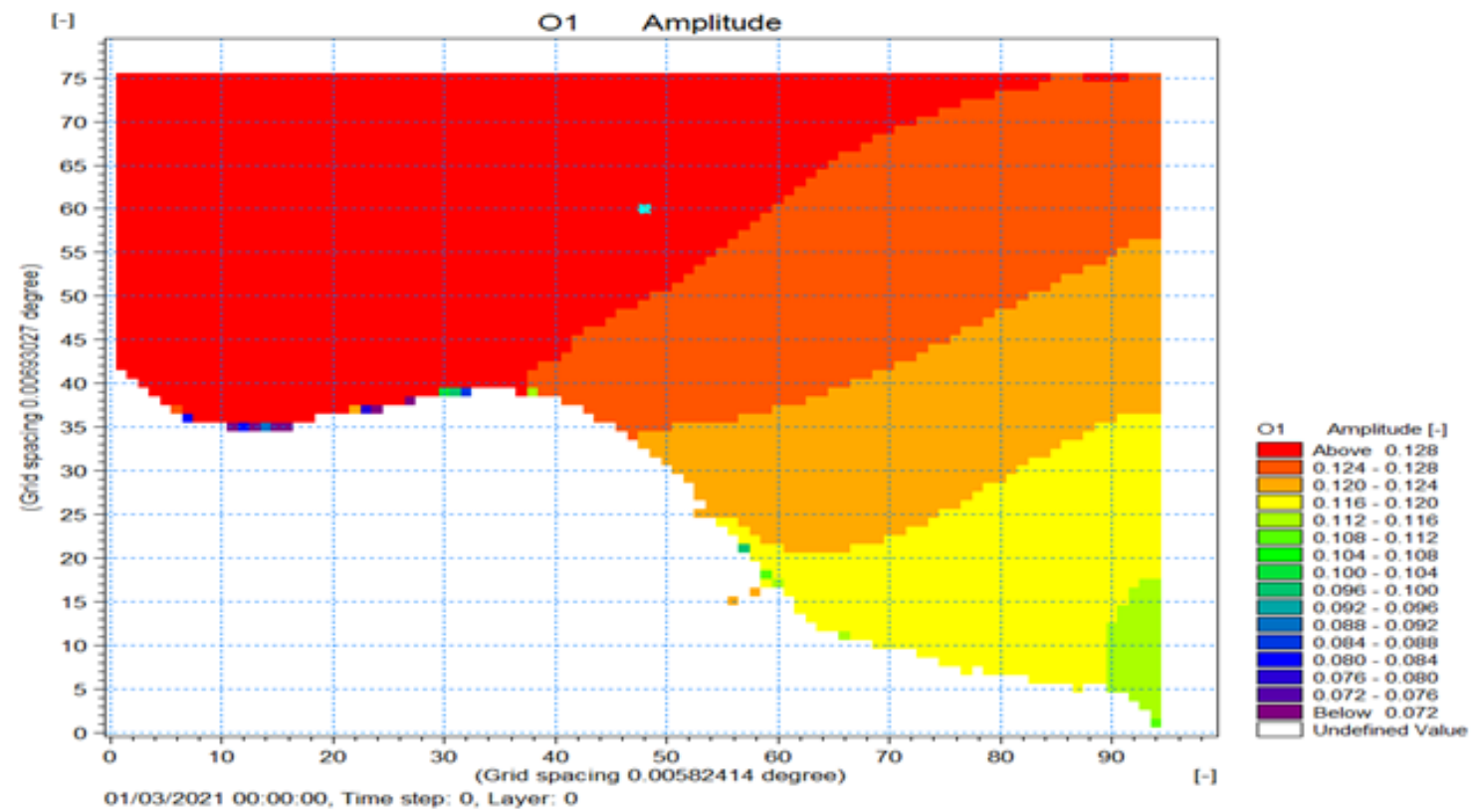

Gambar 9. Komponen Utama Pasang Surut O1

Figure 9. O1 Tidal Main Components

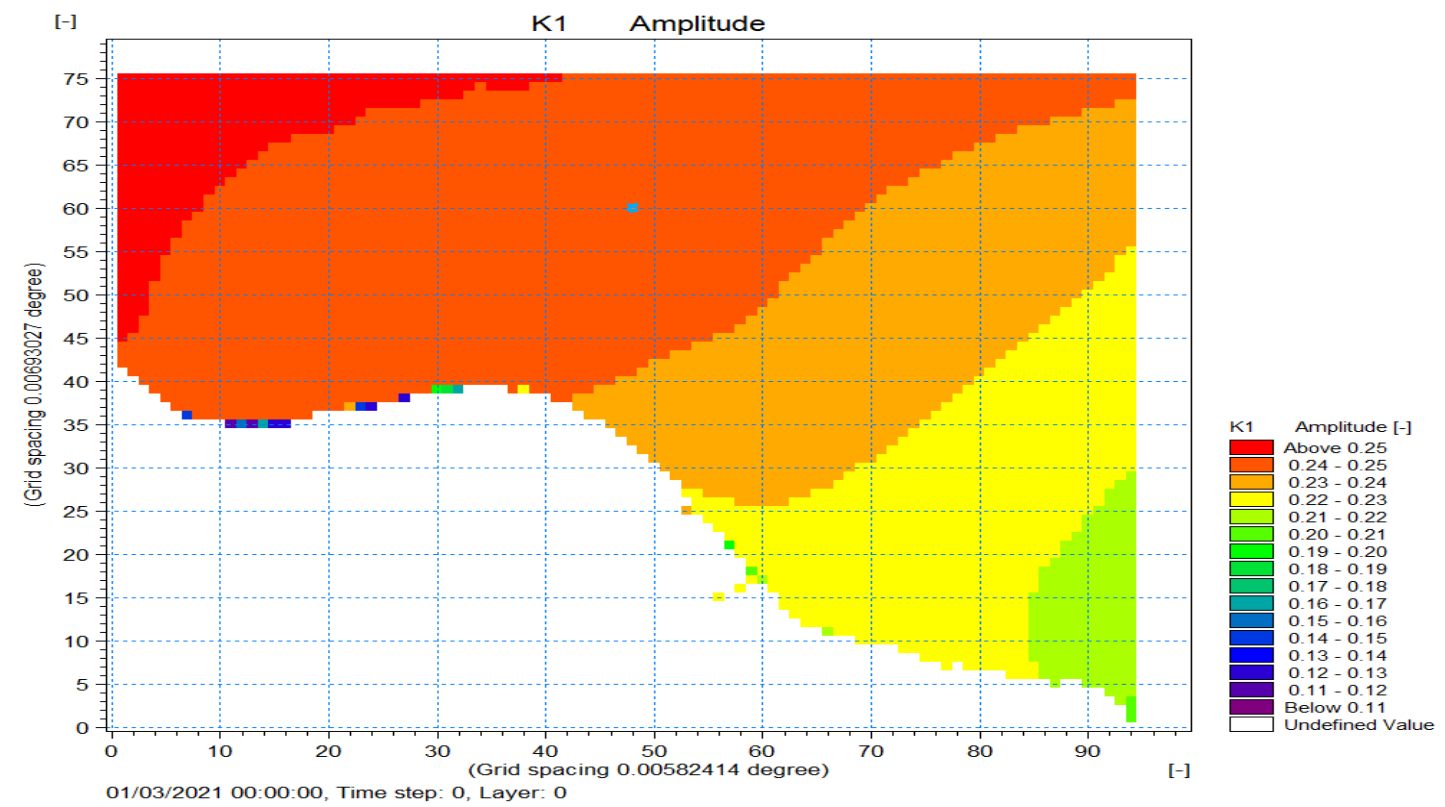

Gambar 10. Komponen Utama Pasang Surut K1

Figure 10. K1 Tidal Main Components

b. Komponen harian ganda (M2 dan S2)

Pasang surut di Pesisir Karawang dengan hasil pemodelan komponen utama pasang surut M2 Amplitudo dengan nilai sebesar 0.055-0.125 (Gambar 11). Peta pasang surut di Pesisir Karawang dengan hasil pemodelan komponen utama pasang surut S2 Amplitudo dengan nilai sebesar 0.0025 0.0375 (Gambar 12). 


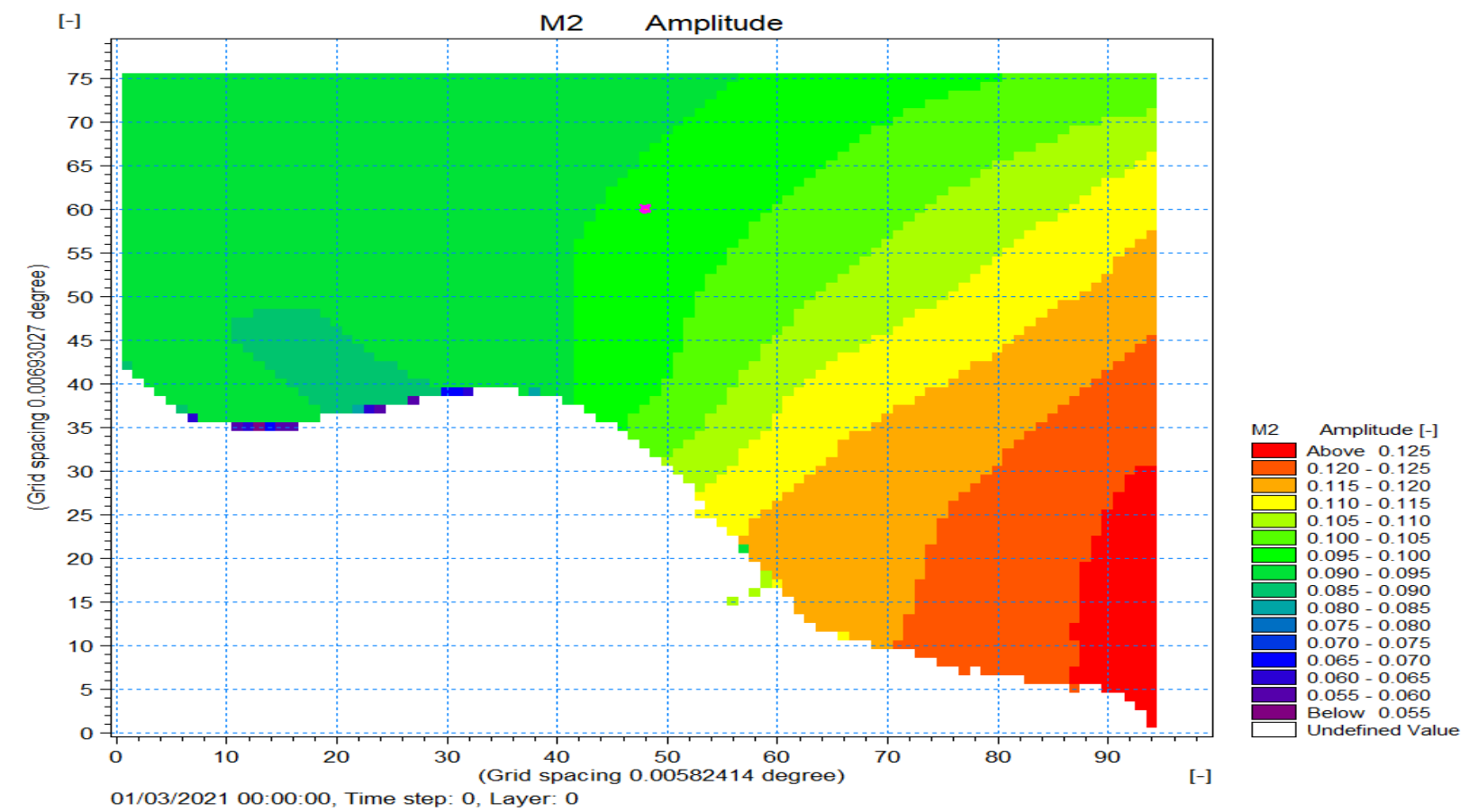

Gambar 11. Komponen Utama Pasang Surut M2 Figure 11. M2 Tidal Main Components

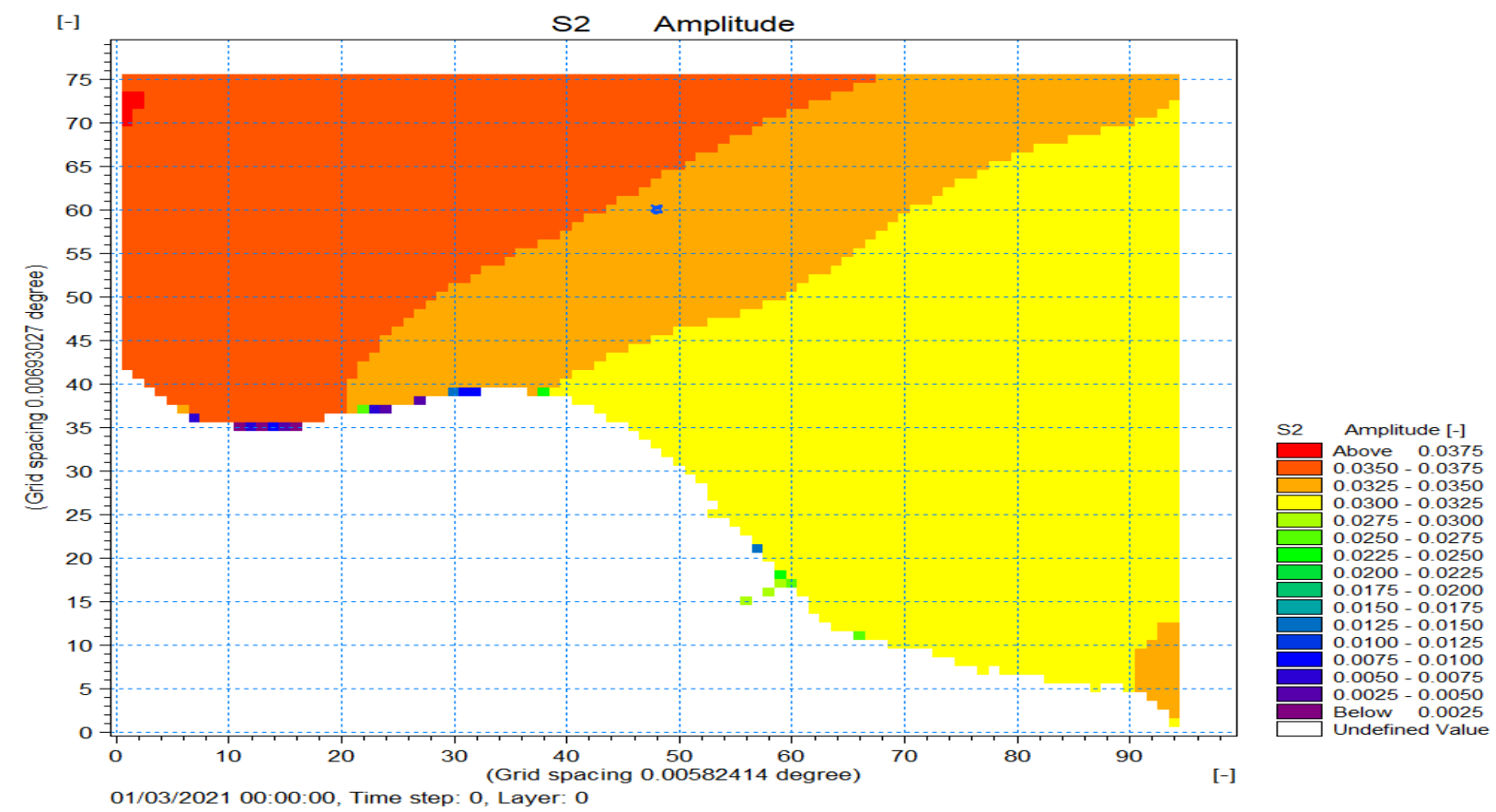

Gambar 12. Komponen Utama Pasang Surut S2

Figure 12. S2 Tidal Main Components

Pemodelan Mike 21 dapat menunjukkan 4 komponen utama pasang surut, yaitu komponen (K1 dan O1) dan komponen (M2 dan S2). Nilai komponen pasang surut tersebut terdapat pada
Tabel 2. Untuk mengetahui tipe pasang surut dilakukan perhitungan menggunakan persamaan Formzahl (Khatimah et al., 2016), sesuai Pers. (1). 


$$
F=\frac{A_{01}+A_{K 1}}{A_{M 2}+A_{S 2}}=\frac{0.129+0.245}{0.097+0.034}=\frac{0.347}{0.131}=2.85
$$

Berdasarkan tipe pasang surut bilangan Formzhal, dengan nilai $1.5<\mathrm{F} \leq$ 3,00 dapat ditentukan tipe pasang surut di daerah pesisir Karawang, yaitu tipe pasang surut campuran dengan condong harian tunggal (Mixed Tide) (Musrifin, 2012; Prasetyo et al., 2016). Tipe pasang surut ini ditandai dengan satu kali pasang dan satu kali surut tetapi terkasang dengan dua kali pasang dan dua kali surut yang sangat berbeda dalam tinggi dan waktu (Wyrtki, 1961).

\section{Model Genangan Banjir Pasang Surut}

Meningkatnya intensitas dan luasan banjir rob di pesisir Karawang diakibatkan kondisi morfologi pantai yang landai dan elevasi rendah, menyebabkan kawasan ini rentan terhadap kenaikan air laut (Shidik et al., 2019). Dalam pemodelan hidrodinamika 2D berdasarkan set up model, model dijalankan dengan batasan domain latitude $(-5,939209-\quad-6,215295)$ dan longitude (107, 098516 - 107, 643533) dengan interval waktu 1 jam dengan dan lama running model 1 bulan yaitu tanggal 1-31 Maret 2021 dengan hasil time step 744. Data ini selanjutnya di modelkan pada Mike 21. Model genangan rob di buat berdasarkan data pesisir Karawang yang di ambil dari peta LPI (Laut Pantai Indonesia) yang kemudian di ekstrak lalu di modelkan.

Pembuatan model genangan banjir rob yang berdasarkan data olahan pada aplikasi Mike 21 dihasilkan luasan genangan pada saat pasang purnama memiliki perbandingan dengan pasang perbani. Pasang purnama dengan nilai pasang tertinggi pada tanggal 08 Maret 2021 dengan interval waktu 2 jam (00:0002:00 WIB) menghasilkan model genangan rob dengan luas daerah genangan tertinggi pada wilayah pesisir Karawang dengan longitude $(107,426-$ $107,474)$ dan latitude $(-6,079--6,145)$ atau sekitar $38,69 \mathrm{~km}^{2}$ yang berada pada pesisir Kecamatan Pedes.

Kondisi pasang perbani saat pasang tertinggi di dapatkan hasil pemodelan seperti (Gambar 13) fenomena tersebut terjadi pada tanggal 13 Maret 2021 terdapat pada time step 331 dari 744 dengan interval waktu 3 jam (17:00 20:00 WIB). Pada kondisi pasang perbani luasan genangan rob yang terjadi di pesisir Karawang mengalami selisih luasan genangan rob terhadap pasang purnama saat pasang tertinggi dengan nilai elevasi berkisar 0,11-0.15 meter.

Pada kondisi pasang purnama saat pasang tertinggi di dapatkan hasil pemodelan seperti pada Gambar 14, terjadi pada tanggal 8 Maret 2021 terdapat pada time step 167 dari 744 dengan interval waktu selama 2 jam (00:00 - 02:00 WIB). Pada kondisi pasang purnama luasan genangan rob yang terjadi di pesisir Karawang mengalami selisih luasan genangan rob terhadap pasang perbani saat pasang tertinggi dengan nilai elevasi berkisar 0.11-0.15 meter. Berdasarkan hasil model olahan data dengan meng-input data pasang surut serta topografi pantai maka dapat dihasilkan prediksi genangan rob di pesisir Karawang pada pasang purnama memiliki nilai elevasi tertinggi 0.20 sampai dengan 0.42 meter. 

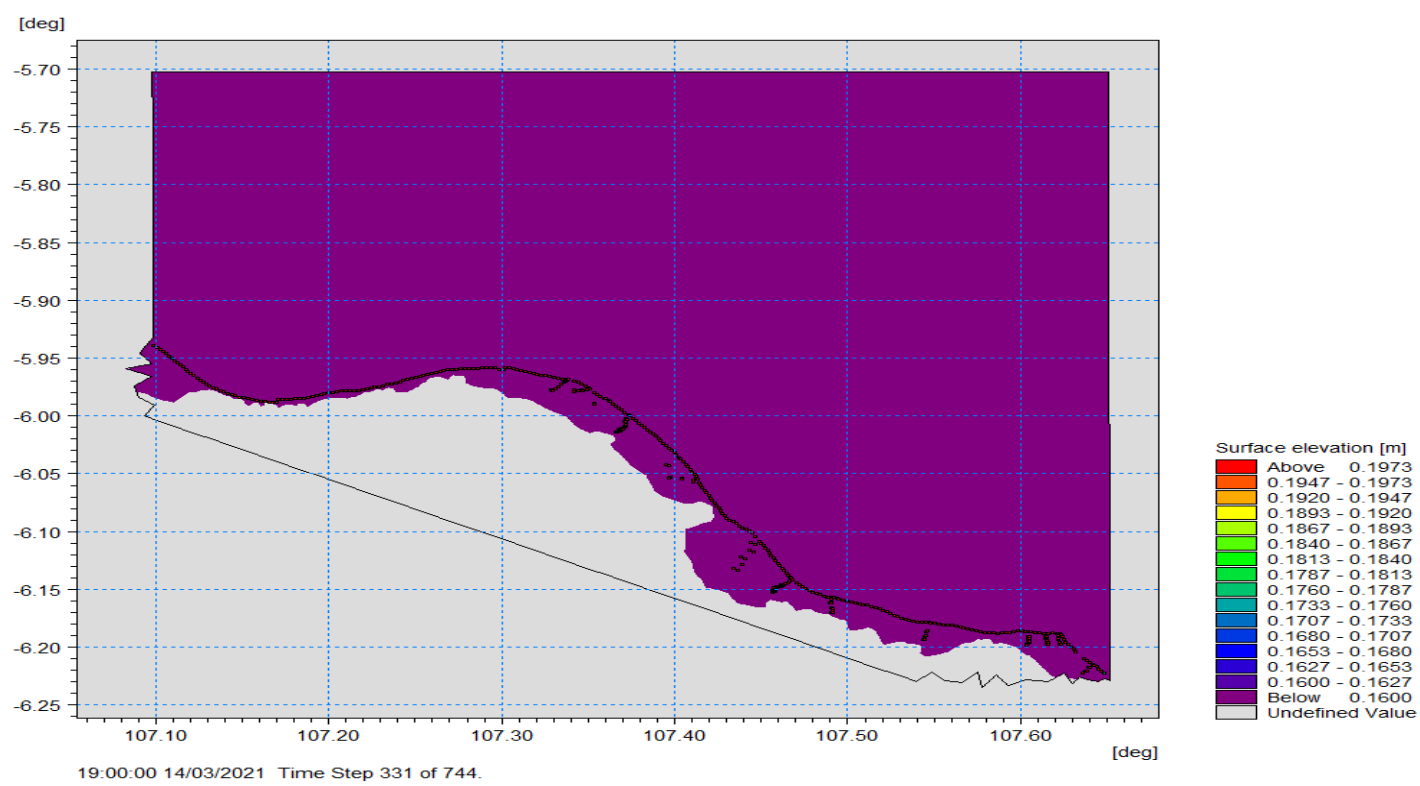

Gambar 13. Pemodelan Genangan Rob Pasang Perbani Figure 13. Modeling of Rob's Tidal Inundation
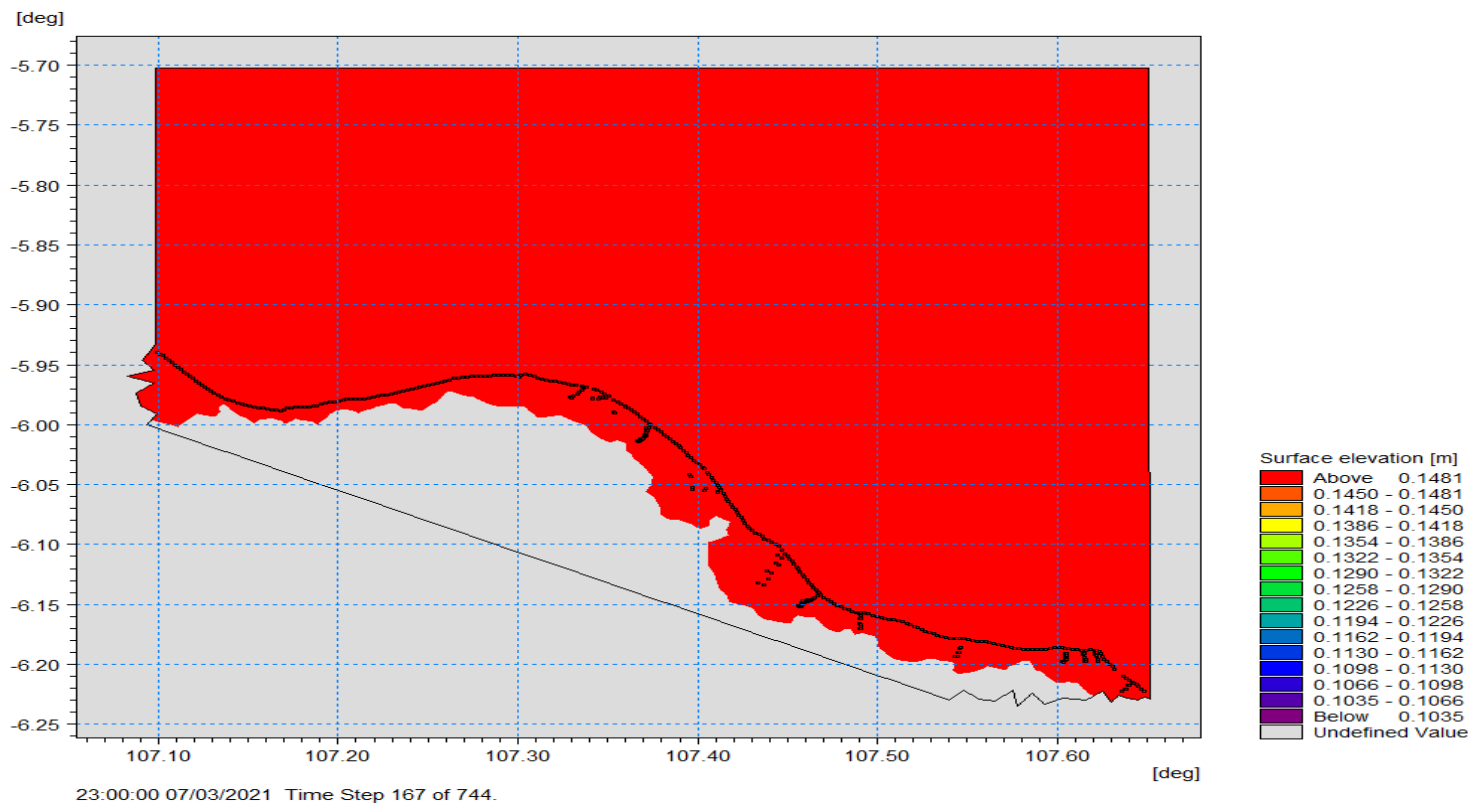

Gambar 14. Pemodelan Genangan Rob Pasang Purnama Figure 14. Modeling of Rob Tidal Inundation

\section{BAHASAN}

Untuk melakukan pemodelan pasang surut di pantai Karawang dilakukan dengan menggunakan software Mike 21 dan metoda yang dilakukan adalah metode flexible mesh. Alasan kenapa mengunakan Software MIKE 21 karena software ini sering digunakan dalam pemodelan data hidrodinamika seperti pemodelan arus, gelombang, pasang surut dan sebagainya. Software ini 
dipakai juga untuk memprediksi dan mensimulasikan proses fisik, kimia dan biologi yang mencakup aliran permukaan dalam bentuk 2D (DHI, 2017). Simulasi model hidrodinamika 2D menggunakan Mike 21 dapat mempresentasikan kondisi hidrodinamika di daerah pengamatan (Leksono et al., 2013). Dalam tahapan penggunaannya software ini perlu menyediakan data-data hidrodinamika yang dibutuhkan dalam pengamatan parameter dimodelkan.

Dalam pemodelan pasang surut ini digunakan data yang diperoleh dari instansi yang menyediakan data secara online di situs masing-masing. Data tersebut setelah diolah dipakai sebagi input data dalam pemodelan pasang surut mengunakan Mike 21. Adapun data tersebut adalah data batimetri, data garis patai, data pasang surut dan data topografi. Data-data terebut setelah didownload kemudian disesuaikan dengan format data Mike 21 .

Hasil simulasi pemodelan pasang surut di pesisir kabupaten Karawang dengan interval waktu 1 jam selama 30 hari menghasilkan nilai amplitudo pasang surut dengan komponen (K1 dan O1) dengan komponen (M2 dan S2). Amplitudo komponen O1 adalah (0.072 $0.128) \mathrm{cm}$, komponen K1 $(0.12-0.25)$ $\mathrm{cm}$, komponen M2 (0.055-0.125) cm dan komponen S2 sebesar (0.0025-0.0375) $\mathrm{cm}$. Dengan nilai kompenen tersebut maka dapat dihitung nilai Formzhal yaitu: $\mathrm{F}=2.854$, dengan nilai Formzhl tersebut dapat ditentukan tipe pasang surut pesisir Karawang yaitu tipe campuran condong harian tunggal (mixed tide prevailing diurnal) (Fadilah et al., 2014).

Kondisi morfologi pesisir Karawang yang relative landai dan mempunyai elevasi rendah serta kondisi pasang surut menyebabkan kawasan ini rentan terhadap kenaikan air laut. Dalam pemodelan hidrodinamika Mike 21 dibuat model genangan rob dengan batasan domain latitude (-5,939209,-6,215295) dan longitude $(107,098516-107,643533)$ dengan interval waktu 1 jam dan lama running model 1 bulan yaitu pada tanggal 1-31Maret 2021 dengan hasil time step 744 (Marfai et al., 2013). Model genangan rob di buat berdasarkan data pesisir Karawang yang di ambil dari peta LPI (Laut Pantai Indonesia) yang kemudian di ekstrak lalu di modelkan.

Pembuatan model genangan banjir rob yang berdasarkan data olahan pada aplikasi Mike 21 dihasilkan luasan genangan pada saat pasang purnama memiliki perbandingan dengan pasang perbani. Pasang purnama dengan nilai pasang tertinggi pada tanggal 08 Maret 2021 dengan interval waktu 2 jam (00:0002:00 WIB) menghasilkan model genangan rob dengan luas daerah genangan tertinggi pada wilayah pesisir karawang dengan longitude $(107,426-$ 107,474) dan latitude $(-6,079$ - -6,145) atau sekitar $38,69 \mathrm{~km}^{2}$ yang berada pada pesisir Kecamatan Pedes.

Pada kondisi pasang perbani luasan genangan rob yang terjadi di pesisir Karawang mengalami selisih luasan genangan rob terhadap pasang purnama saat pasang tertinggi dengan nilai elevasi berkisar 0,11-0.15 meter. Pada kondisi pasang purnama luasan genangan rob yang terjadi di pesisir Karawang mengalami selisih luasan genangan rob terhadap pasang perbani. Berdasarkan hasil model olahan data dengan meng input data pasang surut serta topografi pantai maka dapat dihasilkan prediksi genangan rob dipesisir Karawang pada pasang purnama memiliki nilai elevasi tertinggi 0,20 sampai dengan 0.42 meter.

\section{SIMPULAN}

Berdasarkan hasil dari pemodelan pasang surut di pesisir Karawang dengan menggunakan metode flexible mesh maka dapat disimpulkan sebagai berikut:

1. Software Mike 21 dengan menggunakan metode flexible mesh dapat membuat pemodelan pasang 
surut dan model luas genangan rob di pesisir kabupaten Karawang.

2. Hasil pemodelan pasang surut diperoleh amplitude komponen pasang surut yaitu amplitudo komonen M2 adalah 0.097, amplitudo komponen S2 adalah 0.034, amplitude komponen $\mathrm{K} 1$ adalah 0.245 dan amplitudo komponen O1 adalah 0.129 . Dengan mengunakan rumus Formzhal dapat dihitung nilai Formzhal yaitu 2.854, dengan nilai tersebut ditentukan tipe pasang surut di daerah pesisir Karawang yaitu tipe pasang surut campuran dengan condong harian tunggal.

3. Dari pemodelan dapat dilihat bahwa pasang tertinggi terjadi pada saat pasang purnama tanggal 8 Maret 2021 dengan interval waktu selama 2 jam dan elevasi berkisar 0.20-0.42m. Model genangan memperlihatkan bahwa banjir rob tertingi terjadi pada pada 13 Maret 2021 dengan interval waktu selama 3 jam dan nilai elevasi berkisar 0.11-0.15 m berada pada pesisir Kecamatan Pedes dengan dengan luasan genangan $38,69 \mathrm{~km}^{2}$.

\section{DAFTAR PUSTAKA}

Agus, F., Soeprijadi, L., \& Pasaribu, R. (2020). Kajian Hidro-oseanografi di Perairan Kabupaten Karawang. PELAGICUS, 1(1), 39-51.

Dewi, C. (2010). Tingkat Risiko Banjir Rob di Jakarta Utara. Skripsi. FMIPA, UI. Depok.

Danish Hydrodinamic Institute [DHI]. (2017). MIKE 21 \& MIKE 3 Flow Model FM, Hydrodynamic and Transport Module, Scientific Documentation. Denmark: DHI headquarters (p.64).

Fadilah, Suripin., \& Sasongko, D. P. (2014). Menentukan Tipe Pasang Surut dan Muka Air Rencana Perairan Laut Kabupaten Bengkulu Tengah Menggunakan Metode
Admiralty. Maspari Journal, 6(1), $1-12$.

Hiwari, H., \& Subiyanto. (2020). Pemodelan Arus Permukaan Laut Selat Lembeh, Sulawesi Utara menggunakan Aplikasi Mike 21. Akuatek, 1(2), 84-93.

Irwan, A., Wicaksono, A., \& Khairin, F.A. (2020). Identifikasi Distribusi Beban Sedimentasi pada Intake DAM dan Reservoir PLTA (Studi Kasus: PLTA Cirata, PurwakartaJawa Barat). Journal of Applied Science, 2(1), 22-30.

Khatimah, H., Jaya, I., \& Atmadipoera, A. S. (2016). Pengembangan Perangkat lunak Antar-muka Instrumen Motiwali (Tide Gauge) dengan Analisis Pasang Surut. Jurnal Kelautan Nasional, 11(2), 97-104.

Karana, R.C., \& Supriharjo, R.D. (2013). Mitigasi Bencana Banjir Rob di Jakarta Utara. Jurnal Teknik POMITS, 2(1), 25-30.

Leksono, A., Atmodjo, W., \& Maslukah, L. (2013). Studi Arus Laut Pada Musim Barat di Perairan Pantai Kota Cirebon. Jurnal Oseanografi, 2(3): 206-213.

Marfai, M. A., \& King, L. (2008). Coastal Flood management in Semarang, Indonesia. Environmental Geology, 55 (7), 1507-1518.

Marfai, M.A., Mardiatno, D., Cahyadi, A., Nucifera, F., \& Prihatno, H. (2013). Pemodelan Spasial Bahaya Banjir Rob Berdasarkan Skenario Perubahan Iklim dan Dampaknya di Pesisir Pekalongan. Jurnal Bumi Lestari, 13(2): 244-256.

Musrifin. (2011). Analisis Pasang Surut Perairan Muara Sungai Mesjid Dumai. Jurnal Perikanan dan Kelautan, 16 (1), 48-55.

(2012). Analisis dan Tipe Pasang Surut Perairan Pulau Jemur Riau. Berkala Perikanan Terubuk, 40(1), 101-108. 
Prasetyo, A.A., Zakaria, A., \& Welly, M. (2016). Analisa Kesalahan Pemodelan Data Pasang Surut Stasiun Tanjung Priok. Journal Rekayasa Sipil dan Desain, 4(3), 423-434.

Richasari, D. S., Rohmawati, C. N., \& Fitriana, D. (2019). Analisis Perbandingan Konstanta Harmonik Pasang Surut Air Laut Menggunakan Software GeoTide dan Toga (Studi Kasus: Stasiun Pasang Surut Surabaya, Jawa Timur, Indonesia). Prosiding Seminar Nasional SPI-4. 10 Oktober 2019. ITP Open Conference Systems, Institut Teknologi Padang: 1-8.

Saputra, C. (2007). Studi fluktuasi pasang surut di muara Sungai Siak, Selat Bengkalis dan Tanjung Gadai Perairan Selat Panjang Riau. Skripsi. Ilmu Kelautan, FPIK, UNRI. Riau.

Shidik, A. N., Utari, D., \& Atmika, M. (2019). Analisis Faktor Penyebab Banjir ROB dan Strategi Penanggulangannya dengan
Pembangunan Breakwater di Wilayah Semarang Utara, Jawa Tengah, Indonesia. Prosiding Seminar Nasional Kebumian Ke12. 5-6 September 2019. Teknik Geologi, Fakultas Teknik, Universitas Gajah Mada: 559-575.

Utami, W, S., Subardjo, P., \& Helmi, M. (2017). Studi Perubahan Garis Pantai Akibat Kenaikan Muka Air Laut di Kecamatan Sayung, Kabupaten Demak. Jurnal Oseanografi, 6(1), 281-287.

Wirasatriya, A., Hartoko, A., \& Suripin. (2006). Kajian Kenaikan Muka Laut sebagai Landasan Penanggulangan Rob di Pesisir Kota Semarang. Jurnal Pasir Laut, 1(2), 31-42.

Wyrtki, K. (1961). Physical Oceanography of Southeast Asian Waters. Naga report Volume 2, Scientific Results of Marine Investigations of the South China Sea and the Gulf of Thailand 19591961. University of California. La Lolla. California. 